\title{
Kinetic-Spectrophotometric Determination of Thiocyanate in Human Saliva Based on Landolt Effect in Presence of Astrafloxine FF
}

\author{
Alexander Chebotarev, ${ }^{1}$ Vitaliy Dubovyi, ${ }^{1}$ Dmytro Barbalat, ${ }^{1}$ \\ Elena Guzenko, ${ }^{1}$ Kateryna Bevziuk ${ }^{1}$ and Denys Snigur ${ }^{1, \star}$ \\ ${ }^{1}$ Department of Analytical Chemistry, Odessa I. I. Mechnikov National University, Dvoryanskaya 2, \\ UA-65082 Odessa, Ukraine \\ *Corresponding author: E-mail: 270892denis@gmail.com
}

Received: 09-26-2018

\begin{abstract}
In the present study a kinetic-spectrophotometric method for thiocyanate determination is described. The suggested method for the determination of thiocyanate is based on its "Landolt effect" on the reaction of bromate with hydrobromic acid, which leads to the formation of only one halogen bromine. The reaction was monitored spectrophotometrically at the maximum wavelength of astrafloxine FF light absorption at $535 \mathrm{~nm}$. The absorbance of reactants mixture decreased with an increase of the reaction time. The calibration curve for thiocyanate determination was obtained in the concentration range of $0.03-2.0 \mu \mathrm{g} \mathrm{mL}^{-1}$ under the optimal conditions $\left(\mathrm{pH} 1.5 ; \mathrm{C}_{\mathrm{BrO}_{3}}{ }^{-}=7.6 \times 10^{-4} \mathrm{~mol} \mathrm{~L}^{-1} ; \mathrm{C}_{\text {astrafloxine }} \mathrm{FF}\right.$ $\left.=1 \times 10^{-5} \mathrm{~mol} \mathrm{~L}^{-1}\right)$. The limit of detection was $0.01 \mu \mathrm{g} \mathrm{mL}{ }^{-1}$. The method was successfully applied to the determination of thiocyanate in human saliva samples with satisfactory results.
\end{abstract}

Keywords: Thiocyanate; human saliva; Landolt effect; spectrophotometry; astrafloxine FF.

\section{Introduction}

The toxicity of thiocyanates attracts the attention of specialists in various fields, such as medicine, ecology, food technology, etc., to the problem of developing new and improving existing methods for their determination. ${ }^{1}$ In the human body, thiocyanates are formed during the metabolism of sulfur-containing tobacco substances and some vegetables of the Brassica species or fed with drinking water and food. In biological fluids thiocyanates are also formed as a result of detoxification of cyanides in the liver. ${ }^{2}$ The most common source of inorganic cyanide in the human body is tobacco smoke. Since the content of thiocyanate in body fluids, especially saliva, increases with a constant source of cyanide, which is tobacco smoke, the concentration of thiocyanate in saliva, urine and serum is used as a biomarker to detect smokers. ${ }^{3,4}$

Various analytical methods have been proposed for the determination of thiocyanates. These include the potentiometry with ion-selective electrodes, ${ }^{5}$ electrophoresis, ${ }^{6}$ gas chromatography, and sequential-injection analysis or extraction-spectrophotometric methods. ${ }^{7-10}$
The property of thiocyanates to inhibit the oxidation reaction of dyes (Landolt effect) is the basis of a number of kinetic methods. Landolt reactions have frequently been used for analytical purposes because of their operational and instrumental simplicity and high sensitivity. ${ }^{11-16}$ The spectrophotometric methods for the determination of thiocyanates based on the inhibition of the oxidation of $\mathrm{Me}-$ thyl Orange, ${ }^{12}$ Methyl Red, ${ }^{13}$ Methylene Blue, ${ }^{14}$ Crystalline Violet, ${ }^{15}$ and Janus Green have been proposed. ${ }^{16}$

The main disadvantage of the existing kinetic methods for the determination of thiocyanates based on the Landolt effect is the formation of a mixture of halogens in the interaction of bromate and hydrochloric acid. In this case, the oxidative destruction or halogenation of the dyes occurs at different rates with formation of several products, which leads to poor reproducibility of the measurement results.

To avoid overlapping absorption spectra of the dye and its oxidation/halogenation products, a symmetric dye astrafloxine FF was chosen. The reaction was monitored spectrophotometrically at the maximum wavelength of astrafloxine FF (535 $\mathrm{nm}$ ) while measuring the change in the absorbance over time. 
In this paper, we describe the development of a new method for the determination of thiocyanate, based on its "Landolt effect" on the reaction of bromate with hydrobromic acid, which leads to the formation of bromine. Bromination of astrafloxine FF leads to the formation of only one colorless product.

\section{Experimental}

\section{1. Chemicals and Reagents}

The analytically pure reagents were used, and all solutions were prepared using distilled water. A $0.1 \mathrm{~mol} \mathrm{~L}^{-1}$ stock solution of thiocyanate was prepared by dissolving potassium thiocyanate in water. A $0.01 \mathrm{~mol} \mathrm{~L}^{-1}$ potassium bromate solution was prepared by dissolving $\mathrm{KBrO}_{3}$ in water. A $1 \times 10^{-3} \mathrm{~mol} \mathrm{~L}^{-1}$ solution of astrafloxine $\mathrm{FF}$ was prepared by dissolving dye in $5 \mathrm{~mL}$ of ethanol and diluting to $100 \mathrm{~mL}$ with water. A $2.8 \mathrm{~mol} \mathrm{~L}^{-1}$ hydrobromic acid solution was prepared by dilution of concentrated acid. Solutions with lower concentrations were prepared by the appropriate dilution of more concentrated ones.

\section{2. Instrumentation}

The absorbance measurements were performed using a SF-56 spectrophotometer equipped with thermostate at $25^{\circ} \mathrm{C}$ in $1 \mathrm{~cm}$ quartz cells. The $\mathrm{pH}$ measurements were made using I- $160 \mathrm{M}$ potentiometer with a combined glass electrode. The digital weight balance Axis ANG50C was used for weighing. Centrifuge type MPW-340 was used.

\section{3. General Procedure}

An aliquot of the solution containing thiocyanate was transferred to a $25 \mathrm{ml}$ volumetric flask with the expectation that after dilution its concentration would be in the range $0.03-2.0 \mu \mathrm{g} \mathrm{mL}^{-1}$. Then $1.9 \mathrm{~mL}$ of $0.01 \mathrm{~mol} \mathrm{~L}^{-1}$ potassium bromate solution, $0.3 \mathrm{~mL}$ of $2.8 \mathrm{~mol} \mathrm{~L}^{-1}$ hydrobromic acid solution, and $2.5 \mathrm{~mL}$ of $1 \times 10^{-4} \mathrm{~mol} \mathrm{~L}^{-1}$ astrafloxine FF solution were added. The obtained solution was diluted to $25 \mathrm{~mL}$, mixed and transferred into a quartz cell. The absorbance was recorded as a function of time at $535 \mathrm{~nm}$.

\section{4. Sampling and Sample Preparation}

The saliva samples were collected from a smoking and a non-smoking person. These samples were centrifuged for $5 \mathrm{~min}$ at $3000 \mathrm{rpm}$ and analyzed according to proposed method after appropriate dilution.

\section{Results and Discussion}

\section{1. Reaction Chemistry}

In Landolt processes, a slow reaction is linked to a fast one by the reaction product of the former. ${ }^{11}$ The Landolt effect may be shown as follows:

$$
\begin{aligned}
& \mathrm{A}+\mathrm{B} \rightarrow \mathrm{P}, \\
& \mathrm{P}+\mathrm{L} \rightarrow \mathrm{C},
\end{aligned}
$$

Since the second reaction is faster than the first, its product (P) can only be detected once L (the "Landolt reagent") has disappeared completely as a result of the second reaction.

The reaction of bromate with the hydrobromic acid produces only bromine:

$$
\mathrm{BrO}_{3}^{-}+5 \mathrm{Br}^{-}+6 \mathrm{H}^{+} \rightarrow 3 \mathrm{Br}_{2}+3 \mathrm{H}_{2} \mathrm{O}
$$

A strong oxidative agents such as $\mathrm{Br}_{2}, \mathrm{Cu}(\mathrm{III}), \mathrm{Ce}(-$ $\mathrm{VI})$, and others can cause the decolorization of the astrafloxine $\mathrm{FF}^{17}$ and the bromination reaction mechanism probably can be described by the scheme shown in Fig. 1 . Thiocyanate is a Landolt reagent in the reaction with bromate because the presence of thiocyanate in the solution causes the consumption of the produced $\mathrm{Br}_{2}$, and its reaction with thiocyanate is much faster than dye bromination.

The absorption spectra of astrafloxine FF dye and a product of its decolorisation are shown in Fig. 2.

As can be seen from Fig. 2, the astrafloxine FF dye has an absorbance maximum at $535 \mathrm{~nm}$ and its bromination reaction product is colorless and has absorbance only in UV region.

\section{2. Effects of Variables}

To obtain the maximum sensitivity in the determination of thicyanate, the effects of the media acidity, bromate
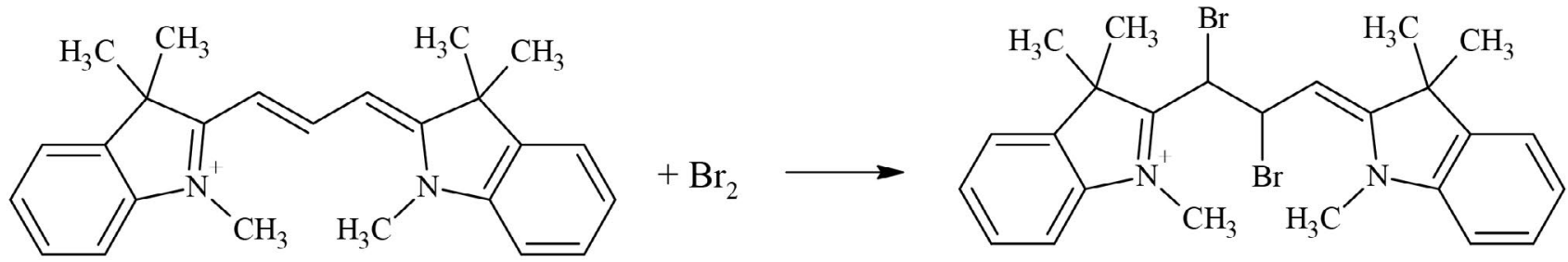

Fig. 1. A probable scheme of astrafloxine FF interaction with bromine in aqueous solution. 


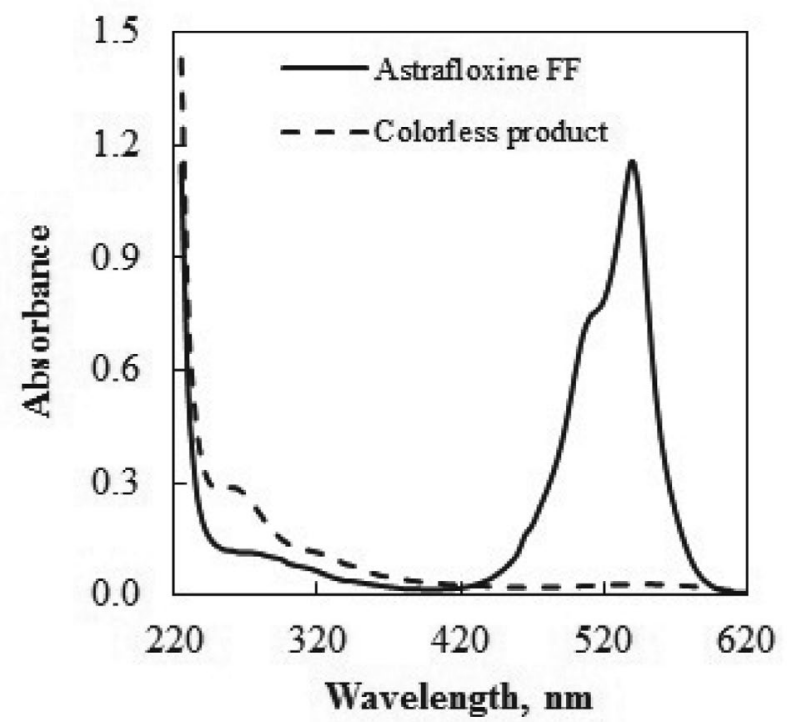

Fig. 2. The absorption spectra of astrafloxine FF dye and a product of its decolorisation, $\mathrm{C}_{\text {astrafloxine } \mathrm{FF}}=1 \times 10^{-5} \mathrm{~mol} \mathrm{~L}^{-1} ; \mathrm{C}_{\mathrm{CNS}^{-}}=2 \times$ $10^{-5} \mathrm{~mol} \mathrm{~L}^{-1} ; \mathrm{C}_{\mathrm{BrO}_{3}}{ }^{-}=7.6 \times 10^{-4} \mathrm{~mol} \mathrm{~L}^{-1} ; l=1 \mathrm{~cm}$.

and astrafloxine FF concentrations were studied. The effect of media acidity was studied in the interval $\mathrm{pH}$ 1.0-3.0 (hydrobromic acid concentration interval was $0.0112-0.112$ $\mathrm{mol} \mathrm{L}^{-1}$ ). When the concentration of hydrobromic acid was more than $0.112 \mathrm{~mol} \mathrm{~L}^{-1}$ hydrobromic acid $(\mathrm{pH}<1)$, the decolorization of astrafloxine FF was coupled almost immediately. At $\mathrm{pH}$ higher than 2 , the reaction takes more than $1 \mathrm{~h}$. Thus, the optimum media acidity was chosen as a compromise. In the case when $\mathrm{pH}$ is 1.5 , the reaction time

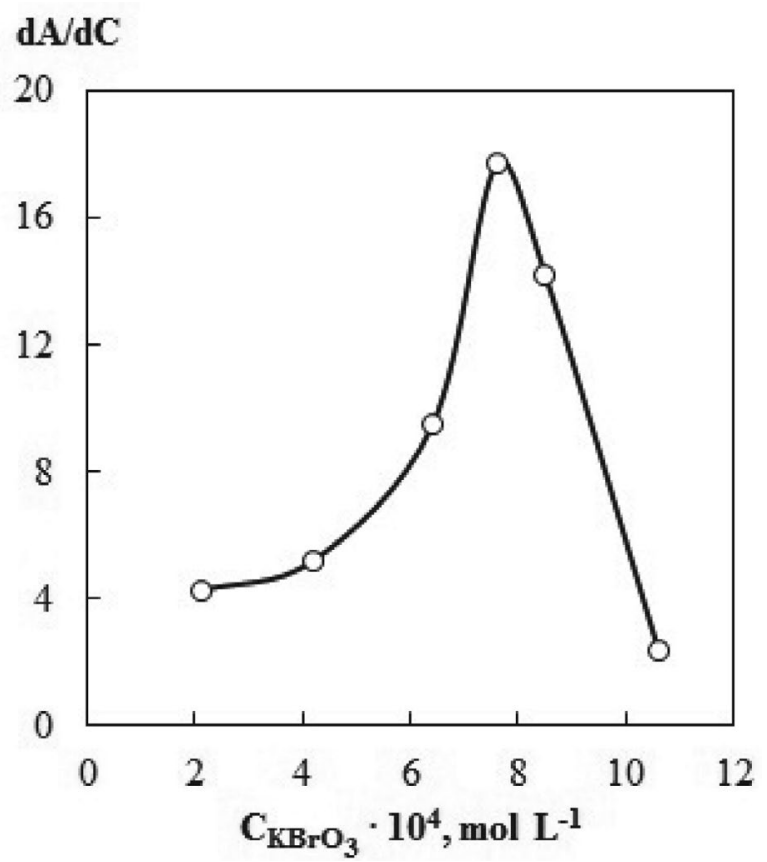

Fig. 3.The differential dependence of absorbance on bromate concentration, $\mathrm{C}_{\text {astrafloxine } \mathrm{FF}}=1 \times 10^{-5} \mathrm{~mol} \mathrm{~L}^{-1} ; \mathrm{pH} 1.5 ; \mathrm{C}_{\mathrm{CNS}^{-}}=2 \times 10^{-5}$ $\mathrm{mol} \mathrm{L}-1, l=1 \mathrm{~cm}$. is about $3 \mathrm{~min}$, which is sufficient for correct registration of the change in absorbance.

The effect of astrafloxine FF concentration on reaction was studied in the range of $5 \times 10^{-6}-5 \times 10^{-4} \mathrm{~mol} \mathrm{~L}^{-1}$. The results showed that astrafloxine FF concentration does not influence the reaction. Therefore, the astrafloxine FF concentration of $1 \times 10^{-5} \mathrm{~mol} \mathrm{~L}^{-1}$ was selected as optimal.

The effect of bromate concentration was also studied. Fig. 3 shows the differential dependence of absorbance on bromate concentration $(\mathrm{dA} / \mathrm{dC}=\mathrm{f}(\mathrm{C}))$.

As can be seen from Fig. 3, a bromate concentration equal to $7.6 \cdot 10^{-4} \mathrm{~mol} \mathrm{~L}^{-1}$ on the differential curve is the maximum. Thus, this concentration was used in further work.

The effect of ionic strength on the kinetics of the oxidation of thiocyanate was not studied in this work, because a number of studies point to the lack of or very weak influence. ${ }^{12-14}$ Despite the fact that the temperature can significantly affect the reaction rate in this study, a temperature of $25{ }^{\circ} \mathrm{C}$ was a priori chosen as the most convenient for routine work.

\section{3. Analytical Figures of Merit and Interference Study}

The slope method was used to construct the calibration plot for kinetic-spectrophotometric determination of thiocyanate (Fig. 4).

In the concentration range $0.03-2.0 \mu \mathrm{g} \mathrm{mL} \mathrm{m}^{-1}$ of thiocyanate, a regression equation: $-\operatorname{tg} \alpha=-5.11 \times 10^{-3} \mathrm{C}_{\mathrm{CNS}^{-}}$ $+1.14 \times 10^{-2}$ with correlation coefficient of 0.99 was ob-

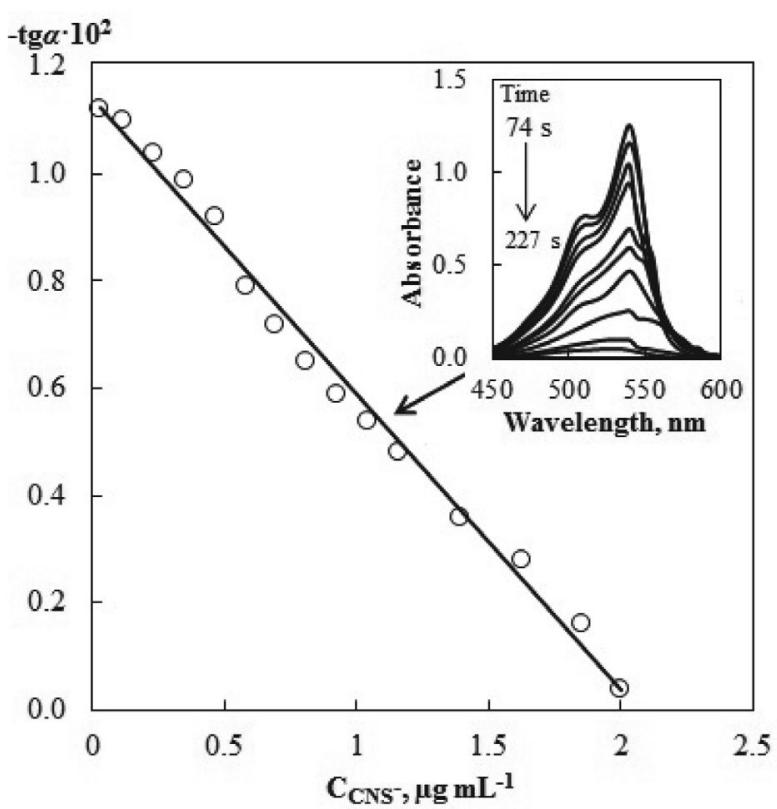

Fig. 4. The calibration plot for kinetic-spectrophotometric determination of thiocyanate by slope method, $\mathrm{C}_{\text {astrafloxine } \mathrm{FF}}=1 \times 10^{-5} \mathrm{~mol}$ $\mathrm{L}^{-1} ; \mathrm{pH} 1.5 ; \mathrm{C}_{\mathrm{BrO}_{3}}{ }^{-}=7.6 \times 10^{-4} \mathrm{~mol} \mathrm{~L}^{-1} ; l=1 \mathrm{~cm}$. 


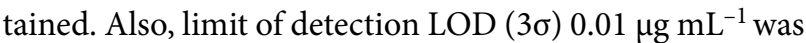
calculated. The reproducibility of the proposed method was determined on the basis of 5 parallel determinations of thiocyanate with a concentration of $1 \mu \mathrm{g} \mathrm{mL}^{-1}$, and the obtained relative standard deviation RSD value was $2.9 \%$.

The effect of some interfering ions on the determination of the $2 \times 10^{-5} \mathrm{~mol} \mathrm{~L}^{-1} \mathrm{CNS}^{-}$by the suggested method was studied and it was established that ions of alkaline metals, alkaline earth metals and a number of other ions did not interfere at the following molar ratios: 1:1500 $\left(\mathrm{Na}^{+}\right.$, $\left.\mathrm{K}^{+}, \mathrm{Ca}^{2+}, \mathrm{Cl}^{-}\right) ; 1: 1000\left(\mathrm{CO}_{3}{ }^{2-}, \mathrm{F}^{-}, \mathrm{PO}_{4}{ }^{3-}, \mathrm{Cu}^{2+}, \mathrm{Mg}^{2+}, \mathrm{Al}^{3+}\right)$; 1:500 $\left(\mathrm{Co}^{2+}, \mathrm{Fe}^{2+}, \mathrm{Fe}^{3+}\right) ; 1: 100\left(\mathrm{SO}_{3}{ }^{2-}, \mathrm{NO}_{2}{ }^{-}, \mathrm{C}_{2} \mathrm{O}_{4}{ }^{2-}\right)$.

\section{4. The Analytical Applications of the Method}

To demonstrate the analytical applications of the proposed method, the non-smoker and smoker human saliva samples were analyzed according to the suggested procedure. The received results are summarized in Table 1. The accuracy and reliability of the proposed method were investigated by applying it to determination of thiocyanate using the standard addition method. High (98.8-99.6\%) recoveries $(\mathrm{R})$ indicated that the suggested kinetic-spectrophotometric procedure was accurate, reliable and can be used for the thiocyanate quantification.

\section{4. Comparison with Literature Studies}

A comparison of the proposed kinetic-spectrophotometric method with other spectrophotometric methods which were reported in literature for thiocyanate determination is given in Table 2. The spectrophotometric method based on formation of $\mathrm{Fe}(\mathrm{III})$-thiocyanate complex is poorly sensitive. ${ }^{18}$ The increased sensitivity of the determination of thiocyanate by kinetic-spectrophotometric methods should be noted. ${ }^{12-16,19,20}$ Methods for the determination of thiocyanate based on the formation and extraction of its ion pair with astrafloxine $\mathrm{FF}$ are also of low sensitivity. ${ }^{9,10}$ Zaruba with coauthors have proposed an original two-in-one device for online monitoring of direct immersion single-drop microextraction for preconcentration and determination of thiocyanate. ${ }^{21}$ This is the first time an optical probe was proposed as the microdrop holder and measuring cell. However, with the simplicity and convenience of this approach, its disadvantages are

Table 1.Determination of thiocyanate in human saliva by the proposed method $(n=5, P=0.95)$

\begin{tabular}{|c|c|c|c|c|c|c|}
\hline Sample & & Spiked, $\mu \mathrm{g} \mathrm{mL} \mathrm{L}^{-1}$ & Found, $\mu \mathrm{g} \mathrm{mL} \mathrm{L}^{-1}$ & RSD, \% & $\mathrm{R}, \%$ & ${ }^{*}$ Thiocyanate concentration \\
\hline \multirow[t]{4}{*}{ Non-smoker saliva } & ${ }^{* *} \mathrm{M}$ & - & $86.25 \pm 2.46$ & 2.3 & - & $51.98-155$ \\
\hline & & 20.0 & $105.8 \pm 3.28$ & 2.5 & 99.6 & \\
\hline & ${ }^{* * *} \mathrm{~F}$ & - & $78.54 \pm 3.02$ & 3.1 & - & \\
\hline & & 20.0 & $99.12 \pm 3.57$ & 2.9 & 100.6 & \\
\hline \multirow[t]{4}{*}{ Smoker saliva } & $\mathrm{M}$ & - & $251.4 \pm 8.74$ & 2.8 & - & $170.23-265$ \\
\hline & & 20.0 & $268.2 \pm 8.99$ & 2.7 & 98.8 & \\
\hline & $\mathrm{F}$ & - & $235.7 \pm 8.49$ & 2.9 & - & \\
\hline & & 20.0 & $254.1 \pm 9.47$ & 3.0 & 99.4 & \\
\hline
\end{tabular}

${ }^{*}$ The interval of thiocyanate concentration $\left(\mu \mathrm{g} \mathrm{mL}^{-1}\right)$ in human saliva according to the literature data; ${ }^{* *}$ Male; ${ }^{\star * *}$ Female; $\mathrm{R}-$ recovery.

Table 2. Comparison of the developed method with some other methods of thiocyanate determination with spectrophotometric detection

\begin{tabular}{|c|c|c|c|c|}
\hline Method & Reagent $(\lambda, \mathbf{n m})$ & Linearity, $\mu \mathrm{g} \mathrm{mL} \mathrm{mL}^{-1}$ & $\mathrm{LOD}, \mu \mathrm{g} \mathrm{mL} \mathrm{L}^{-1}$ & Ref. \\
\hline Spectrophotometry & $\mathrm{Fe}\left(\mathrm{NO}_{3}\right)_{3}(447)$ & $2-100$ & - & 18 \\
\hline Kinetic-spectrophotometry & Methyl Orange (525) & $2 \times 10^{-7}-4 \times 10^{-5}$ * & $7 \times 10^{-8^{*}}$ & 12 \\
\hline Kinetic-spectrophotometry & Methyl Red (520) & $0.05-1.1$ & 0.0025 & 11 \\
\hline Kinetic-spectrophotometry & Ferroine $/ \mathrm{IO}_{4}^{-}(510)$ & $0.02-0.2$ & 0.016 & 19 \\
\hline Kinetic-spectrophotometry & 4-amino- $N, N$ - & & & \\
\hline diethylanilinesulphate $/ \mathrm{Fe}^{3+}(515)$ & $0.05-0.5$ & 0.012 & 20 & \\
\hline DLLME $^{*}$ & Astrafloxine FF (555) & $3.1-28.2$ & 0.11 & 9 \\
\hline $\operatorname{SIA}^{* *}$ & Astrafloxine FF (555) & $2.9-29$ & 1.16 & 10 \\
\hline DI-SDME ${ }^{* *}$ & Astrafloxine FF (555) & $0.29-4.35$ & 0.12 & 21 \\
\hline Kinetic-spectrophotometry ${ }^{* *}$ & Astrafloxine FF (535) & $0.03-2.0$ & 0.01 & This work \\
\hline
\end{tabular}

DI-SDME - direct immersion single drop microextraction; DLLME - dispersive liquid-liquid microextraction; SIA - sequential injection analysis; ${ }^{*}$ concentration given in $\mathrm{mol} \mathrm{L}^{-1}$; ${ }^{* *}$ ion pair formation between thiocyanate and astrafloxine $\mathrm{FF}$ and its extraction; ${ }^{* * *}$ decolorization of astrafloxine FF 
low sensitivity and the need for optical probe with a special design. Also, the micropumping multicommutation flow system was successfully applied to determine thiocyanate in human saliva samples. ${ }^{22}$ In general, the proposed kinetic-spectrophotometric method for the determination of thiocyanate based on the decolorization of astrafloxine FF can be attributed among the most sensitive methods. At the same time, the proposed method lacks the disadvantages of other kinetic methods, namely, poor reproducibility.

\section{Conclusions}

In this study, a novel, accurate and sensitive kinetic-spectrophotometric procedure for determination of thiocyanate trace concentrations has been reported. The method for the determination of thiocyanate is based on its "Landolt effect" on the reaction of bromate with hydrobromic acid, which leads to the formation of only one halogen bromine and promotes decolorization of astrafloxine FF. The reaction was monitored spectrophotometrically at the maximum wavelength of astrafloxine $\mathrm{FF}$ at $535 \mathrm{~nm}$. The limit of detection was $0.01 \mu \mathrm{g} \mathrm{mL}^{-1}$. The method was successfully applied to the determination of thiocyanate in human saliva samples with satisfactory results.

\section{References}

1. Z. Glatz, P. Bouchal,O. Janiczek, M. Mandl, P. Ceskova, J. Chromat. A. 1999, 838, 139-148.

2. Z. Glatz, S. Novakova, H. Sterbova, J. Chromat. A. 2001, 916, 273-277.

3. G. F. Wang, M.G. Li, Y.C. Gao, B. Fang, Sensors, 2004, 4, 147-155. DOI:10.3390/s40900147

4. S. Narkowicz, E. Jaszczak, Ż. Polkowska, B. Kiełbratowska, A. Kotłowska, J. Namieśnik, Biomed. Chromatogr. 2018, 32, e4111. DOI:10.1002/bmc.4111

5. N. Giorgio, Anal. Chem. 1975, 47, 763-764.

DOI:10.1021/ac60354a002
6. C. Bjergegaard, P. Muller, H. Sorensen, J. Chromat. A. 1995, $717,409-414$.

7. Y. Tanaka, N. Naruishi, H. Fukuya, J. Sakata, K. Saito, S. Wakida, J. Chromatogr. A. 2004, 1051, 193-197. DOI:10.1016/S0021-9673(04)00979-3

8. S. Kage, T. Nagata, K. Kudo, J. Chromatogr. B. 1996, 675, $27-$ 32. DOI:10.1016/0378-4347(95)00344-4

9. V. Andruch, C. C. Acebal, J. Škrliková, H. Sklenářová, P. Solich, I. S. Balogh, F. Billes and L. Koćurová, Microchem J. 2012, 100, 77-82. DOI:10.1016/j.microc.2011.09.006

10. C. C. Acebal, H. Sklenářová, J. Škrliková, I. Śŕamková, V. Andruch, I.S. Balogh and P. Solich, Talanta, 2012, 96, 107-112. DOI:10.1016/j.talanta.2012.01.021

11. D. Perez-Bendito and M. Silva, Kinetic Methods in Analytical Chemistry, 1st ed. Ellis Horwood, Chichester, 1988, 330.

12. T. Madrakian, A. Esmaeili, A. Abdolmaleki, J. Anal. Chem. 2004, 59, 28-32.

DOI:10.1023/B:JANC.0000011664.22353.e3

13. J. Ghasemi, R. Amini, A. Afkhami, Anal. Sci. 2001, 17, 435437. DOI:10.2116/analsci.17.435

14. M. R. Shishehbore, N. Nasirizadeh, A.A. Kerdegari, Anal. Sci. 2005, 21, 1213-1216. DOI:10.2116/analsci.21.1213

15. G. Bagherian, M.A. Chamjangali, Z. Berenji, Eurasian J. Anal. Chem. 2008, 3, 307-317.

16. M. Keyvanfard, K. Alizad, P. Elahian, J. Chem. 2013, 2013, $1-5$.

17. I. S. Balogh, M. Ruschak, V. Andruch, Y. Bazel, Talanta. 2008, 76, 111-115. DOI:10.1016/j.talanta.2008.02.011

18. J. Hovinen, M. Lahti, J. Vilpo, J. Chem. Educ. 1999, 76, 12811282. DOI:10.1021/ed076p1281

19. A. Afkhami, H. Bahrami, Anal. Letters. 1995, 28, 1785-1791.

20. V. R. Igov, R. M. Simonovic, R. P. Igov, Facta Univ. Ser. Phys., Chem. Technol. Univ. Nis. 2002, 2, 209-213. DOI:10.1080/00032719508000356

21. S. Zaruba, A. Vishnikin, J. Škrliková, A. Diuzheva, I. Ozimaničová, K.Gavazov, V. Andruch, RSC Advances. 2017, 7, 29421-29427. DOI:10.1039/C7RA02326J

22. J. J. Silva Júnior, M. A. Farias, V. L. Silva, M. C. B. S. M. Montenegro, A. N. Araújo, A. F. Lavorante, A. P. S. Paim, Spectrosc. Lett. 2010, 43, 213-219.

DOI:10.1080/00387010903287094

\section{Povzetek}

V predstavljeni študiji opisujemo kinetično spektrofotometrično metodo za določanje tiocianata. Predlagana metoda za določanje tiocianata je osnovana na njegovem "Landoltovem učinku" na reakcijo med bromatom in bromovodikovo kislino, ki vodi do nastanka ene molekule broma. Reakcijo spremljamo spektrofotometrično pri absorpcijskem maksimumu astrafloksina FF pri $535 \mathrm{~nm}$. Absorbanca reakcijske mešanice se zmanjšuje z naraščanjem reakcijskega časa. Umeritveno krivuljo za določitev tiocianata smo pridobili v koncentracijskem območju $0,03-2,0 \mu \mathrm{g} \mathrm{mL}^{-1}$ pod optimalnimi pogoji $\left(\mathrm{pH} 1,5 ; \mathrm{C}_{\mathrm{BrO}_{3}}{ }^{-}=7,6 \times 10^{-4} \mathrm{~mol} \mathrm{~L}^{-1} ; \mathrm{C}_{\text {astrafloksin } \mathrm{FF}}=1 \times 10^{-5} \mathrm{~mol} \mathrm{~L}^{-1}\right)$. Meja zaznave je bila $0,01 \mu \mathrm{gg} \mathrm{mL}^{-1}$. Metodo smo uspešno uporabili za določitev tiocianata $\mathrm{v}$ vzorcih človeške sline $\mathrm{z}$ zadovoljivimi rezultati. 